\title{
URGENSI BIMBINGAN KEAGAMAAN ISLAM TERHADAP PEMBENTUKAN KEIMANAN MUALAF
}

\author{
Anton Widodo \\ Institut Agama Islam Negeri (IAIN) Metro \\ Jl. Ki Hadjar Dewantara 15 A Kota Metro Lampung 34111 \\ Antonwidodo211@gmail.com
}

\begin{abstract}
Abstrack
The Urgency of Islamic Religious Guidance Against the Formation of Faith This convert is an Islamic religious guide to the formation of converts' faith applied to converts who are problematic or not, because basically with the Islamic guidance Muslim converts will always remember Allah and be a straight way to reach a calmer and directed life. . Islamic religious guidance is done by lectures, religious discussions, and outpouring of the heart. In addition, there are daily programs such as congregational prayers, qiyamul lail material, there are also certain times such as the commemoration of Islamic holidays, Islamic studies with direct methods or indirect methods. The urgency of Islamic religious guidance is: First, it produces a change, improvement, and mental and mental hygiene which was initially still insecure so that the soul of the converts becomes calm and peaceful, behaves broadly, and to reach enlightenment the guidance of the Lord feels lighter. Second, to produce a change in courtesy that can benefit both yourself, the family environment, work environment and the social environment and the natural environment. Third, to produce social sensitivity in individuals so that tolerance and solidarity arise and develop, help and love. Social piety will make motivation to improve the antibody system from akhlaq almadmumah so that ahkhlaq al-karimah is always maintained. Fourth, to produce spiritual intelligence in the individual so that a sense of desire arises to obey his Lord, sincerity in obeying all His commands and endurance to accept His test. The whole urgency and principle above is a means to improve the quality of the faith that grows and grows stronger, which originally will increase the taqlid faith into the faith of science so that it reaches the highest point, namely faith haq and essence.
\end{abstract}

Keywoard : Islamic Religion, Mualaf Faith 


\section{A. PENDAHULUAN}

Kehidupan yang serba terbuka menjadikan ruang persoalan hidup menjadi semakin kompleks dan beragam, baik yang berasal dari diri maupun dari luar, sehingga tanpa disadari kebutuhan spiritual merupakan keniscayaan pada diri manusia. Spiritual yang kokoh akan menjadikan seseorang berpegang teguh pada keyakinan agama yang dianutnya yakni keimanan. Iman yang berarti percaya menunjuk sikap batin yang terletak dalam hati. beriman kepada Allah berarti amat sangat rindu terhadap ajaran Allah, yaitu al-Qur'an dan Sunnah Rasul.

Hal itu karena apa yang dikehendaki Allah, menjadi kehendak orang yang beriman, sehingga dapat menimbulkan tekad untuk mengorbankan segalanya dan kalau perlu mempertaruhkan nyawa. Seseorang dinyatakan iman bukan hanya percaya terhadap sesuatu, melainkan kepercayaan itu mendorongnya untuk mengucapkan dan melakukan sesuatu sesuai dengan keyakinan. Berbicara iman bukan hanya dipercayai atau diucapkan, melainkan menyatu secara utuh dalam diri seseorang yang dibuktikan dalam perbuatannya

Karunia terbesar dari Allah Swt kepada hamba-Nya adalah karunia keimanan, dengan keimanan kebaikan menjadi manfaat, kebajikan menjadi maslahat, dan sumber kebahagiaan baik di dunia maupun di akhirat. Keimanan juga dapat dijadikan sebagai motivator, dinamisator dan sumber kebaikan tertinggi dalam kehidupan manusia di dunia. Iman merupakan dasar segala amal perbuatan manusia. Iman adalah imam (pemimpin) tertinggi yang akan memimpin manusia kepada tujuan dan akhlak yang baik

Konsep iman pada dasarnya sangat luas karena mencakup seluruh aspek kepribadian dan kehidupan manusia. Akan tetapi arti dan tujuan serta pengaruh iman terkadang terasa dangkal bahkan mengalami inflasi sehingga dampaknya bagi tingkah laku dan perbuatan manusia tidak beguterlihat. Padahal orang yang beriman adalah orang yang dekat dengan Allah Swt. serta memperoleh kesuksesan dalam kehidupannya di dunia dan akhirat. Mengapa orang mudah mengatakan iman di mana-mana, akan tetapi dalam kehidupan dan tingkah lakunya tidak kelihatan nilai-nilainya. Salah satu jawabannya adalah orang tersebut tidak memiliki visi yang benar tentang iman, sehingga keimanan tersebut tidak merasuk ke dalam 
jiwanya dan tidak membuahkan amal kebaikan dan ketaatan.

Agar keimanan bisa merasuk ke dalam jiwa dan dapat membuahkan amal kebaikan dan ketaatan maka perlu ditanamkan dalam jiwa rasa ingin dan terus belajar terlebih pada persoalan keagamaan dengan landasan bimbingan yang kuat Fitrah manusia tidak akan selamanya bisa dijaga oleh pemiliknya. Seperti halnya mereka ketika beranjak dewasa akan semakin tahu tentang dosa, namun mereka bisa saja melanggarnya. Kefitrahan seorang bisa jadi hilang akibat dosa yang mereka lakukan, apalagi seperti masyarakat awam yang minim akan pengetahuan agama. Guna membentuk perilaku jamaah yang menjadi lebih baik dan ada benteng untuk menjaga kefitrahan tersebut, salah satunya yaitu dengan bimbingan keagamaan. Pada dasarnya hal ini merupakan pranata keagamaan yang sudah dianggap baku oleh masyarakat. Dengan demikian, tradisi keagamaan sudah menjadi kerangka acuan norma dalam kehidupan berperilaku masyarakat.

Keagamaan memang menjadi kebudayaan yang sudah mentradisi, karena persoalan ini menyangkut dengan kehormatan, keharmonisan, harga diri, dan jati diri masyarakat. Bimbingan keagamaan merupakan upaya untuk membantu seorang individu di masyarakat agar belajar mengembangkan fitrah atau kembali kepada fitrah, dengan memberdayakan keimanan dan akal, serta kemauan yang dikaruniakan Allah Swt yang sifatnya berhubungan dengan agama. Dilain persoalan, bimbingan keagamaan penting untuk membantu individu mewujudkan dirinya sebagai manusia seutuhnya agar mencapai kebahagiaan hidup di dunia dan akhirat.

Pemaparan tersebut memberikan pemahaman bahwa bimbingan keagamaan memang dibutuhkan dalam kegiatan keimanan seseorang untuk menyadari dan mengembangkan eksistensinya kembali pada fitrah manusia. Begitu juga halnya bimbingan agama yang diberikan kepada seorang yang baru memulai perjalanan spiritualitasnya dalam agama yakni seorang mualaf, dimana biasanya bimbingan tersebut diberikan dengan tujuan supaya mualaf mampu memahami arti keimanan dan ketaqwaan kepada Allah, tujuan dan makna hidup di dunia ini. Tahap proses pelaksanaan bimbingan agama Islam seorang pembimbing atau dai memberikan bantuan kepada seseorang yang mengalami kesulitan baik lahiriyah maupun batiniyah di 
masa kini maupun di masa mendatang.

Beberapa bantuan berupa pertolongan dibidang mental dan spiritual, ada pada dirinya sendiri melalui dorongan yang muncul dari kekuatan iman dan taqwa seseorang pada Tuhanya. Selanjutnya pemberian bimbingan, pelajar dan pedoman dalam rangka mengatasi problematika hidup agar keinginan mencapai ketentraman hidupnya selaras dengan petunjuk Allah. Sebagai seorang muslim yang beriman, maka perlu ditanamkan dengan penuh keyakinan, bahwa Islam adalah agama yang benar dan murni mengamalkan ajaran Tauhid (mengesakan Tuhan). Islam adalah agama yang sarat dengan nilai, maka orang yang menerima Islam adalah orang yang melakukan dan menjadikan nilai-nilai itu sebagai pengikat pada Islam.

Diantara nilai-nilai itu adalah nilai keimanan, setiap yang mengaku Islam ia terikat untuk mengimani agama ini sebagai satu-satunya agama yang benar. Kebenaran itu bersifat universal dan eternal. Sifat universal itu berlaku untuk seluruh manusia, dan sifat eternal itu berlaku sampai hari kiamat. Nilai yang lain adalah nilai perbuatan. Berislam bukan hanya beriman, tetapi juga beramal. Dalam hal ini, setiap muslim dituntut untuk mengamalkan apa yang diimaninya. Islam adalah mempunyai makna kedamaian, kepatuhan, penyerahan (diri), ketaatan, dan kepatuhan. Hal itu juga berlaku bagi mereka yang mengalami perpindahan agama dari agama non Islam kepada agama Islam (muallaf)

Persoalan lain pada mualaf biasanya ketika memeluk Islam dilarang pulang ke rumah orang tuanya atau saudara mereka tidak lagi menganggap mereka, bahkan sampai dimarahi dan dicaci maki, serta berbagai isolasi sosial yang mereka alami, ditambah pula gaya hidup mereka yang dahulu juga sudah berubah dari minum alkohol, memakan babi dan sebagainya, kesemuanya harus mereka tinggalkan dengan serta- merta. Perubahan yang drastis ini merupakan ${ }^{1}$ masa yang sukar bagi mereka. Bimbingan kita sebagai Muslim amat penting bagi mereka mencapai ketenangan di dalam keimanan kepada aqidah Islam. Pada kesimpulannya, mualaf memerlukan banyak bantuan dan sokongan moral dari kita. Perubahan di dalam hidup mereka ini merupakan perubahan yang terbesar dan

1 Mustofa Kurdi.. Dakwah Dibalik Kekuasaan. Bandung: 2012 Remaja Rosda karya hal 120 
drastis. Disamping itu, pembinaan mualaf yang kurang optimal akibat perhatian umat Islam yang kurang, selain itu juga disebabkan minimnya inovasi atau pembaruan teknik dalam berdakwah di kalangan pembina. Kalau kita lihat, sangat sedikit masjid dan ormas Islam yang peduli dengan para mualaf terutama dalam aspek pembinaannya.

Minimnya inovasi itu juga tidak terlepas dari kurangnya sumber daya manusia yang mumpuni untuk membangun fondasi keimanan yang dibutuhkan para mualaf. Kewajiban bagi umat Islam untuk terus menyisihkan waktu dan pikiran untuk membuat semacam gebrakan dalam pembinaan mualaf di tanah air. Urgensi Bimbingan Keagamaan Islam terhadap Pembentukan Keimanan Mualaf ini ditulis dengan harapan mampu memberikan kontribusi baik dorongan sosial maupun spiritual kepada para mualaf bahwa mereka tidak sendiri dalam menjalankan keyakinan dan mempelajari agama Islam.

\section{B. PENGERTIAN BIMBINGAN AGAMA ISLAM}

Bimbingan merupakan proses membantu individu untuk bisa memahami dirinya dalam menyelasaikan masalah yang dihadapi. Menurut Bruce Shretzer dan Shaelly C. Stone, bimbingan diartikan sebagai the process of helping individuals to understand themselve and their world. ${ }^{2}$

Bimbingan adalah bantuan yang diberikan kepada individu atau kelompok (sekelompok orang) agar mereka itu dapat mandiri, melalui berbagai bahan, interaksi, nasehat, gagasan, alat dan asuhan yang didasarkan atas norma-norma yang berlaku. bimbingan adalah proses yang melibatkan seseorang professional berusaha membantu orang lain dalam mencapai pemahaman diri (self understanding), membuat keputusan dan pemecahan masalah.

Hakekat bimbingan adalah upaya pemberian bantuan kepada 1) individu oleh konselor kepada individu yang membutuhkan dengan ikhlas dan hanya mengharap ridlo Allah SWT semata. Dikatakan bantuan karena pada dasarnya individu sendiri yang harus aktif "memahami" dan "mentaati" aturan Allah SWT dalam kehidupan sehari-sehari. ${ }^{3}$

2 Bruce, Shertzer dan Shaelly C. Stone. Fundamental of Guidance. Boston: Houghton Mifflin Company 1966 hal 31 $\mathrm{w} / 15$

${ }^{3}$ http://jurnalbki.uinsby.ac.id/index.php/jurnalbki/issue/vie 
Bimbingan dan konseling adalah proses yang bertujuan menolong seseorang yang mengidap kegoncangan emosi sosial yang belum sampai pada tingkat kegoncangan psikologis atau kegoncangan akal, agar ia dapat menghindari diri dari padanya. Dari beberapa deskripsi diatas dapat dipahami bahwa bimbingan secara umum adalah suatu proses pemberian bantuan yang dilakukan oleh seorang ahli kepada seorang atau beberapa orang, agar mampu mengembangkan potensi bakat, minat, dan kemampuan yang dimiliki, mengenali dirinya sendiri, mengatasi persoalan-persoalan sehingga mereka dapat menentukan sendiri jalan hidupnya secara bertanggung jawab tanpa bergantung kepada orang lain.

Rumusan di atas merupakan rumusan bimbingan secara umum sehingga perlu dikemukakan bimbingan dari sudut pandang Islami seperti yang dirumuskan Musnamar bahwa bimbingan Islami adalah proses pemberian bantuan terhadap individu agar mampu hidup selaras dengan ketentuan dan petunjuk Allah, sehingga dapat mencapai kebahagiaan hidup di dunia dan di akherat. ${ }^{4}$ Lebih lanjut Faqih juga memberikan penelasan tentang bimbingan dari sudut pandang Islami yakni, proses pemberian bantuan terhadap individu agar dalam menjalankan kehidupan selaras dengan ketentuan dan petunjuk Allah, sehingga dapat mencapai kebahagian di dunia dan akhirat $^{5}$.

Bahkan menurut Hellen, Bimbingan Islam adalah suatu usaha membantu individu dalam menanggulangi penyimpangan perkembangan Fitrah beragama yang dimilikinya, sehingga ia kembali menyadari peranannya sebagai khalifah di bumi dan berfungsi untuk menyembah, mengabdi kepada Allah Swt. sehingga akhirnya tercipta kembali hubungan baik dengan Allah, dengan manusia dan alam semesta ${ }^{6}$.

Selanjutnya dari sudut pandang Islam yang dirumuskan oleh Adz-Dzaky suatu aktivitas memberikan bimbingan pelajaran dan pedoman kepada individu yang meminta

4 Tohari Musnamar, Dasar-Dasar Konseptual Bimbingan da Konseling Islam, Yogyakarta: UII Press 1992 hal 5

5 Faqih, Aunur Rohim.. Bimbingan dan Konseling dalam Islam. Yogyakarta: UII Press 2001 hal 84

6 Hallen. A. Bimbingan dan Konseling Cet. I. Jakarta: Ciputat Press 2001 hal 22 
bimbingan (klien) dalam hal bagaimana seharusnya seorang klien dapat mengembangkan potensi akal pikirannya, kejiwaannya, keimanan dan keyakinan serta dapat menanggulangi problematika hidup dan kehidupannya dengan baik dan benar secara mandiri dan berparadigma kepada al-Quran dan asSunnah7 ${ }^{7}$ Rumusan di atas dapat peneliti simpulkan bahwa bimbingan agama Islami adalah proses pemberian bantuan terhadap individu agar dalam menjalankan kehidupannya senantiasa menyadari eksistensinya sebagai makhluk Allah dan selaras dengan ketentuan dan petunjuk- Nya, dapat mengembangkan potensi akal pikirannya, kejiwaannya, keimanan dan keyakinan sehingga dapat mencapai kebaahagiaan dunia dan akhirat.

\section{DASAR BIMBINGAN AGAMA ISLAM}

Dasar dari bimbingan agama Islam adalah al-Qur'an dan as- Sunnah, sebab keduanya merupakan sumber utama yang digunakan sebagai pedoman oleh umat Islam. Hal ini sesuai dengan firman Allah dalam QS. Al Imran ayat 104 dan QS. Yunus ayat 57:

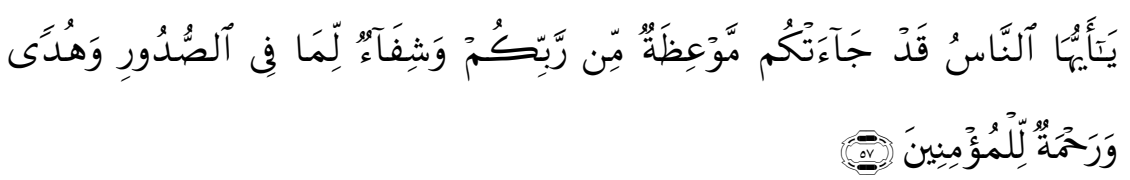

Artinya: Hai manusia, Sesungguhnya telah datang kepadamu pelajaran dari Tuhanmu dan penyembuh bagi penyakitpenyakit (yang berada) dalam dada dan petunjuk serta rahmat bagi orang-orang yang beriman.

Ayat-ayat tersebut dapat diketahui bahwa kita diwajibkan menyeru atau mengingatkan kepada kebaikan. Dan itu dapat kita lakukan melalui bimbingan agama Islam atau bimbingan penyuluhan Agama. Karena dengan agama dapat menuntun kita kearah jalan kebenaran sehingga kita akan meraih kebahagiaan di dunia dan di akhirat

7 Bakran adz-Dzaky, M. Hamdani.. Psikoterapi dan Konseling Islam. Yogyakarta: Fajar Pustaka Baru 2001 hal 137 


\section{TUJUAN BIMBINGAN AGAMA ISLAM}

Tujuan daripada bimbingan Agama Islam yaitu supaya seseorang mampu memahami arti dan makna hidup, untuk meningkatkan kualitas keimanan dan ketaqwaan kepada Allah, terwujudnya pengetahuan Islami secara paripurna dan terpadu yang terjangkau pada seluruh masyarakat, sehingga dapat memberikan motivasi sebagai pendorong dalam proses pemahaman agama yang lebih mendalam ${ }^{8}$.Tujuan tersebut akan tercapai jika mualaf diberikan skala prioritas semisal tujuan jangka pendek yang ingin dicapai dengan adanya bimbingan keagamaan adalah agar individu memahami dan menaati tuntutan Al-Quran.

Tercapainya tujuan jangka pendek ini diharapkan individu yang dibimbing memiliki keimanan yang kuat, dan secara bertahap mampu meningkatkan kualitas kepatuhannya kepada Allah Swt, yang terlihat dalam bentuk kepatuhan terhadap hukum-hukum Allah dalam pelaksanaan amanah yang diberikan kepadanya, dan ketaatan dalam peribadahan sesuai tuntunanNya. Untuk jangka panjang yang ingin dicapai adalah agar individu yang dibimbing secara bertahap bisa berkembang menjadi pribadi yang lebih baik. Secara garis besar tujuan bimbingan konseling Islam dapat dirumuskan untuk membantu individu mewujudkan dirinya sebagai manusia seutuhnya agar mencapai kebahagiaan hidup di dunia dan di akhirat. Sementara itu, tujuan bimbingan agama Islam dalam tujuan umum dan tujuan khusus. Tujuan umumnya adalah membantu individu mewujudkan dirinya sebagai manusia seutuhnya agar mencapai kebahagiaan hidup di dunia dan di akhirat. Tujuan khususnya adalah membantu individu untuk mengatasi masalah yang dihadapinya.membantu individu memelihara dan mengembangkan situasi dan kondisi yang baik atau yang tetap baik menjadi tetap baik atau menjadi lebih baik, sehingga tidak akan menjadi sumber masalah bagi dirinya dan orang lain ${ }^{9}$

Unsur-Unsur Bimbingan Agama Islam Bimbingan Agama Islam mempunyai beberapa unsur atau komponen yang saling terkait dan berhubungan antara satu sama lain. Unsur-unsur

8 Tohari Musnamar,. Dasar-Dasar Konseptual Bimbingan dan Konseling Islam, : (Yogyakarta)1992.UII Press hal 72

9 Faqih, Aunur Rohim.. Bimbingan dan Konseling dalam Islam. Yogyakarta: 2001 UII Press hal 35 
bimbingan agama Islam pada dasarnya adalah terkait dengan konselor, konseli dan masalah yang dihadapi. Penyuluh (dai) Penyuluh (dai) adalah orang yang amat bermakna bagi jamaah, penyuluh menerima apa adanya dan bersedia sepenuh hati membantu jamaah mengatasi masalahnya disaat yang amat kritis sekalipun dalam upaya menyelamatkan konseli dari keadaan yang tidak menguntunkan baik untuk jangka pendek dan utamanya jangka panjang dalam kehidupan yang terus berubah ${ }^{10}$

Yusuf Penyuluh Islam adalah seseorang yang memiliki kemampuan untuk melakukan konsultasi berdasarkan standar profesi. Penyuluh Islam dalam tugasnya membantu jamaah menyelesaikan masalah kehidupannya, harus memperhatikan nilai-nilai dan moralitas Islami ${ }^{11}$. Sebagai seorang teladan, seharusnya konselor Islam menjadi rujukan dan menjadi barometer bagi konseli dalam menjalankan kehidupan. Tugas Penyuluh pada dasarnya adalah usaha memberikan bimbingan kepada jamaah dengan maksud agar jamaah mampu mengatasi permasalahan dirinya. ${ }^{12}$ Dalam memberikan bantuan kepada individu tentu tidak dilakukan oleh sembarangan orang. Tapi harus mempunyai karakteristik tersendiri yang dimilikinya. Diantara karakteristik tersebut yaitu: Pertama Seorang penyuluh harus menjadi cerminan bagi jamaah. Kedua Kemampuan bersimpati dan berempati yang melampaui dimensi duniawi. Ketiga Menjadikan bimbingan sebagai awal keinginan bertaubat yang melegakan. Keempat Penyuluh harus menempati moralitas Islam, kode etik, sumpah jabatan, dan janji. Selain memiliki karakteristik, penyuluh Islam harus memiliki beberapa persyaratan diantaranya:

Pertama Penyuluh Islam hendaklah orang yang menguasai materi khususnya dalam masalah keilmuan agama Islam. Kedua Penyuluh Islam hendaklah orang yang mengamalkan nilai-nilai agama Islam dengan baik dan konsekuen, tercermin melalui keimanan, ketakwaan, dan pengalaman keagamaan dalam kehidupannya sehari-hari. Ketiga Penyuluh Islam sedapat mungkin mampu mentransfer kaidahkaidah agama Islam secara garis besar yang relevan dengan

\footnotetext{
${ }^{10}$ Latipun.. Psikologi Konseling. Malang: 2001 UMM Press hal 45

11 Yusuf, Syamsul \& Juntika Nurihsan.. Landasan Bimbingan $\mathcal{E}$ Konseling.

12 Bandung: PT Remaja Rosdakarya 2011 hal 260
} 
masalah yang dihadapi jamaah. Keempat Penyuluh Islam hendaknya menguasai metode dan strategi yang tepat dalam menyampaikan bimbingan dan konseling kepada jamaah, sehingga jamaah dengan tulus akan menerima nasihat penyuluh. Adapun Bimbingan agama Islam setidaknya dilakukan beberapa orang yang di anggap ahli dalam bidangnya diantaranya dalah Ahli bimbingan konseling, Ahli psikologi, Ahli pendidikan, Ahli agama, Dokter ,Pekerja sosial ${ }^{13}$

1. Jamaah (Mad'u)

Menurut Willis, jamaah/klien adalah individu yang diberi bantuan oleh seorang penyuluh atas permintaan sendiri atau atas permintaan orang lain ${ }^{14}$ Sedangkan menurut Roger yang dikutip oleh Latipun menyatakan bahwa jamaah itu adalah orang atau individu yang datang kepada konselor dan kondisinya dalam keadaan cemas atau tidak karuan. ${ }^{15}$ Klien itu manusia yang mempunyai masalah, dan manusia itu sendiri pada hakikatnya tidak akan pernah lepas dari yang namanya masalah, namun ada klien yang mampu menghadapi masalahnya dengan bijaksana dan sebaliknya ada juga klien yang menghadapi masalahnya dengan gejolak emosi yang tidak terkendali. Jadi dapat disimpulkan bahwa klien adalah seorang individu yang mempunyai masalah dan datang kepada konselor untuk menyelesaikan masalahnya karena dirinya sendiri tidak sanggup untuk menyelesaikan masalahnya. Dalam menyelesaikan permasalahan klien tersebut, ada syarat-syarat tertentu yang harus diketahui oleh seorang konselor agar proses konselingnya bisa berjalan dengan lancar, syarat- syarat tersebut diantaranya: Klien yang dibantu adalah klien yang beragama Islam atau non Islam yang bersedia diberi bantuan melalui pendekatan dengan menggunakan nilai-nilai Islam. Klien adalah individu yang sedang mengalami hambatan atau masalah untuk mendapatkan ketentraman atau

13 Farid, Imam Sayuti. 1997. Pokok-Pokok Bahasan Tentang Bimbingan

14 Willis, Sofyan S.. Konseling Individual Teori dan Praktek. Bandung: Alfabeta

15 Latipun $0 p$ Cit.. hal 48 
kebahagiaan hidup ${ }^{16}$. Klien datang secara sukarela atau kesadarannya. Klien merupakan seseorang yang berhak menentukan jalan hidupnya sendiri, dan akan bertanggungjawab atas dirinya setelah baligh atau dewasa untuk kehidupan di dunia atau di akhirat. Pada dasarnya setiap klien adalah baik, karena Allah Swt telah membekali potensi berupa fitrah suci untuk selalu tunduk pada peraturan Allah Swt. Ketidak tentraman atau ketidak bahagiaan klien dalam hidupnya umumnya bersumber dari belum dijalankannya ajaran agama sesuai tuntutan AlQuran dan Al-Hadis, sehingga perlu didiagnosis secara mendalam bersama klien. Klien yang bermasalah pada hakikatnya orang yang membutuhkan bantuan untuk memfungsikan jasmani, qolb, a'qal, dan basirahnya dalam pengendalian hawa nafsunya ${ }^{17}$

\section{Metode}

Adalah jalan yang harus dilalui untuk mencapai suatu tujuan, karena kata metode berasal dari meta yang berarti melalui dan hodos berarti jalan. Metode lazim diartikan sebagai jarak untuk mendekati masalah sehingga diperoleh hasil yang memuaskan, sementara teknik merupakan pernerapan metode tersebut dalam praktek. Metode bimbingan Islam berbeda halnya dengan metode dakwah. Sebagai kita ketahui metode dakwah meliputi: metode ceramah, metode tanya jawab, metode debat, metode percakapan antar pribadi, metode demonstrasi, metode dakwah Rasulullah SAW, pendidikan agama dan mengunjungi rumah (silaturrahmi). ${ }^{18}$

\section{Materi}

Materi bimbingan agama Islam sama saja dengan materi dakwah Islam, karena apa yang terdapat dalam materi bergantung pada tujuan yang yang ingin dicapai.

16 Penyuluhan Agama Sebagai Teknik Dakwah. Surabaya: Fakultas Dakwah IAIN Sunan Ampel 2013 hal 53

17 Santoso, Agus dkk, Terapi Islam. Surabaya: IAIN SA Press

18 Aunur Rohim Faqih,Bimbingan dan Konseling dalam Islam. Yogyakarta: UII Press 2001 hal 53 
Sebagaimana yang telah disebutkan dalam Al-Quran, bahwa: "Tujuan umum dakwah adalah mengajak ummat manusia (meliputi orang mukmin maupun kafir atau musyrik) kepada jalan yang benar yang diridhai Allah SWT, agar dapat hidup bahagia dan sejahtera didunia maupun diakhirat". Menurut Shihab ${ }^{19}$ yang disampaikan seorang bimrohis atau da'i dalam proses penanaman nilainilai dan ajaran- ajaran Islam untuk mengajak manusia kepada jalan yang diridhai Allah, serta mengubah perilaku mad'u agar mau menerima ajakan serta memanifestasikannya, agar mendapat kebaikan dunia akhirat, itulah yang disebut materi bimbingan.Materi dakwah pada garis besarnya dapat dibagi dua: Al-Qur'an dan Hadits. Pokok-pokok ajaran Islam yaitu: aqidah, ibadah, akhlaq, dan mu'amalah mencakup pendidikan, ekonomi, sosial, politik, budaya dan lain-lain

Menurut Syukir secara global, materi dakwah dapat diklasifikasikan menjadi tiga hal, yang pada dasarnya ketiganya bersumber dari Al-Quran dan Hadits. Tiga hal itu adalah ${ }^{20}$ :

Pertama Masalah keimanan (aqidah) Aqidah dalam Islam adalah bathni bersifat i'tiqad bathiniyah yang mencangkup masalah-masalah yang erat hubungannya dengan rukun iman.

Kedua Masalah keislaman (syar'iyah) Dalam Islam, permasalahan syar'iyah erat kaitannya dengan perbuatan nyata dalam mentaati semua peraturan/hukum Allah untuk mengatur hubungan antara manusia dengan tuhannya serta mengatur pergaulan hidup antar sesama manusia. Permasalahan yang berhubungan dengan masalah syar'iyah bukan saja terbatas pada masaalah ibadah kepada Allah, namun permasalahannya juga mencakup pada masalah yang berkenaan dengan pergaulan hidup antar sesama manusia seperti masalah hukum jual-beli, berumah tangga, warisan, dan lainnya, begitu juga dengan segala bentuk larangan Allah, seperti mabuk, mencuri, berzina, dan sebagainya. Hal itu juga termasuk masalah yang menjadi materi dakwah.

19 Shihab, Quraish.. Membumikan al-Quran Memfungsikan Wahyu dalam Kehidupan, jilid 2. Ciputat Tangerang: Lentera Hati hal 2011 143144

20 Syukir, Asmuni, Dasar-dasar Strategi Dakwah Islam. Surabaya: Al-Ikhlas1983 hal 80 
Ketiga Masalah budi pekerti (akhlaqul karimah) Sebagai materi dakwah, akhlak lebih tepat dikatakan pelengkap bagi keimanan dan keislaman seseorang. Namun bukan berarti masalah akhlak tidak penting, karena bagaimana pun juga, iman dan islam seseorang tidak akan sempurna tanpa dibarengi dengan perwujudan akhlakul karimah. Rasullulah pun pernah bersabda: "Aku diutus oleh Allah SWT didunia ini hanyalah untuk menyempurnakan Akhlak"

Ketiga Sarana Prasarana Suksesnya layanan bimbingan didukung oleh adanya pendayagunaan semua sarana dan prasarana bimbingan secara efektif dan efisien. Sarana prasarana merupakan alat penunjang dalam proses bimbingan di Majlis Taklim Al-Harokah seperti perpustakaan, ruang konsultasi, kartu tanda anggota dan lain sebagainya. Sarana prasarana ini digunakan untuk konsultasi berbagai hal mulai masalah keagamaan sampai masalah duniawi yang diampu oleh tim pembimbing.

\section{E. TAHAPAN BIMBINGAN AGAMA ISLAM}

Tahapan bimbingan agama Islam yang harus dilalui pembimbing dan jamaah yaitu:

1. Tahap Perencanaan

Pertemuan pertama dengan klien sangat penting untuk merencanakan dan memperoleh data awal latar belakang klien dalam mengindentifikasi masalah yang dihadapi klien tersebut. Pada tahap ini konselor berusaha mendorong anggota keluarga untuk terlibat dalam proses penentuan aturan dasar bimbingan konseling ${ }^{21}$ Menurut Salahudin tahap ini juga diseut diagnosis yaitu langkah untuk menetapkan masalah yang dihadapi anak berdasarkan latar belakangnya. Kegiatan dilakukan dengan mengumpulkan data dan menyelaraskan studi terhadap klien, menggunakan berbagai studi dan teknik pengumpulan data. Setelah data terkumpul, ditetapkan masalah yang dihadapi serta latar belakangnya ${ }^{22}$. Selain itu, pembimbing dapat kembali menegaskan tujuan yang harus dicapai dalam bimbingan agama Islam. Hal ini

${ }^{21}$ Hellen..Op Cit hal 13

22. Salahudin Anas Setia.. Bimbingan dan Konseling. Bandung: Pustaka Setia 2010 hal 95 
dimaksudkan untuk menyadarkan dan menyegarkan klien pada makna kehadirannya terlibat dalam bimbingan agama. Biasanya klien hanya akan menceritakan hal-hal umum yang ada dalam dirinya dan belum mengungkapkan permasalahannya.

\section{F. PEMBENTUKAN KEIMANAN MUALAF}

\section{Pengertian Pembentukan Keimanan}

Benih iman yang dibawa sejak dalam kandungan memerlukan pembinaan yang berkesinambungan. Pengaruh pedidikan keluarga secara langsung maupun tidak langsung sangat berpengaruh terhadap iman seseorang. Proses pembentukan iman diawali dengan proses perkenalan. Megenal ajaran Allah harus dilakukan sedini mungkin sesuai dengan kemampuan sendiri. Selain pengenalan, proses pembiasaan juga perlu diperhatikan, agar senantiasa melaksanakan ajaranajaran Allah. Inti iman adalah membenarkan di dalam qalbu (keyakinan mendalam akan kebenaran yang disampaikan), ikrar dengan lisan untuk menyebarkan kebenaran dan merealisasikan iman dengan mengikuti contoh Rasul ${ }^{23}$.

Iman menurut bahasa adalah tashdiiq (mempercayai), sedangkan menurut istilah ada-lah mempercayai Rasulullah dan berita yang di bawanya dari Allah. Ungkapan Iman adalah "perkataan dan perbuatan, dapat bertambah dan berkurang". Yang dimaksud dengan "perkataan" adalah ucapan dua kalimat syahadat, yang dimaksud dengan "perbuatan"adalah mencakup perbuatan hati (keyakinan) dan perbuatan anggota badan (ibadah). Ulama terdahulu mengatakan bahwa iman adalah mempercayai dengan hati, diucapkan dengan lisan dan diamalkan dengan anggota badan.

Quraish Shihab menjelaskan pengertian iman menurut bahasa adalah "pembenaran". Sebagian pakar mengartikannya

${ }^{23}$ Al-Naisaburi, al-Imam Abi al-Husain Muslim Ibn al-Hajjaj alQusyairi, Shahih Muslim Jilid II. Beirut: Darul Kutub Al-`Ulumiyyah 1992 hal 92 
sebagai "pembenaran hati terhadap apa yang didengar oleh telinga". Menurut mereka pembenaran akal saja tidak cukup, yang lebih penting adalah pembenaran hati. Dari sudut pandangan Islam tidak semua pembenaran dinamakan iman. Iman terbatas pada pembenaran yang menyangkut apa yang disampaikan oleh Nabi Muhammad saw.

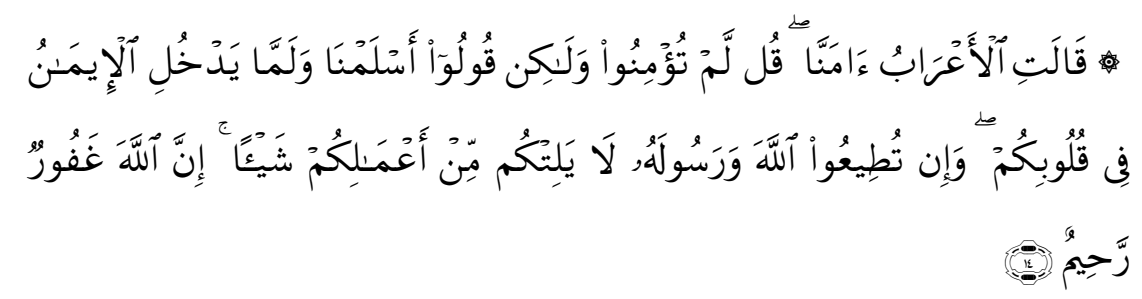

Artinya: orang-orang Arab Badui itu berkata: "Kami telah beriman". Katakanlah: "Kamu belum beriman, tapi Katakanlah 'kami telah tunduk', karena iman itu belum masuk ke dalam hatimu; dan jika kamu taat kepada Allah dan Rasul-Nya, Dia tidak akan mengurangi sedikitpun pahala amalanmu; Sesungguhnya Allah Maha Pengampun lagi Maha Penyayang."

Konsep iman yang sesungguhnya dalam Islam bukanlah keimanan dalam arti taqlidi atau tamanni atau keimanan yang hanya dalam bentuk ucapan dan angan-angan belaka, yang tidak berdasarkan pada pengetahuan serta bersifat pasif. Akan tetapi, konsep keimanan yang dikehendaki oleh ajaran Islam adalah iman yang hakiki, yaitu keimanan kepada Allah dan alam ghaib yang membuahkan amal yang didasarkan atas ilmu dan keyakinan hati, sehingga bersifat aktif dan dinamis. Antara iman dan amal, perkataan dan perbuatan, teori dan praktek, serta kehidupan lahir dan batin tidak dapat dipisahkan dalam Islam karena keduanya ibarat dua sisi mata uang yang tidak terpisahkan adanya. Dapat juga disimpulkan bahwa pengertian iman adalah pembenaran yang hakiki dan utuh yang menghunjam ke dalam hati serta membuahkan amal-amal ketaatan untuk meraih sukses dan kebahagiaan dalam kehidupan dunia dan akhirat ${ }^{24}$ Keimanan juga merupakan keyakinan yang sungguh-sungguh yang tidak bercampur Pustaka1997 257

24, M. Utsman Najati, Al-Quran wa, Ilmu al-Nafs (terj.),Bandung: 
dengan keraguan serta berpengaruh baik pada pikiran, perasaan, kemauan dan tingkah laku. Najati secara detail mengklasifikasikan sifat-sifat orang beriman menjadisembilan bidang perilaku:

1. Sifat-sifat yang berkenaan dengan aqidah: beriman kepada Allah, para rasul-Nya, kitab-kitab-Nya, malaikat, hari akhir, kebangkitan dan perhitungan, surga dan neraka, hal yang ghaib dan qadar.

2. Sifat-sifat yang berkenaan dengan ibadah: menyembah Allah, melaksanakan kewajiban shalat, puasa, zakat, haji, berjihad di jalan Allah dengan harta dan jiwa, bertaqwa kepada Allah, mengingat-Nya selalu, memohon ampun kepada-Nya, berserah diri kepada-Nya, dan membaca al-Quran.

3. Sifat-sifat yang berhubungan dengan hubungan sosial: bergaul dengan orang secara baik, dermawan dan suka berbuat kebajikan, suka bekerjasama, tidak memisahkan diri dari kelompok, menyeru kepada kebaikan dan mencegah kemungkaran, suka memaafkan, mementingkan kepentingan orang lain dan menghindar dari hal-hal yang tidak ada manfaatnya.

4. Sifat-sifat yang berkenaan dengan hubunganhubungan kekeluargaan: berbuat baik kepada orang tua dan kerabat, pergaulan yang baik antara suami dan istri, menjaga dan membiayai keluarga.

5. Sifat-sifat moral: sabar, lapang dada, lurus, adil, melaksanakan amanat, menepati janji kepada Allah dan kepada manusia, menjauhi dosa, teguh dalam kebenaran dan di jalan Allah swt., luhur jiwa, mempunyai kehendak yang kuat, mampu mengendalikan hawa nafsu.

6. Sifat-sifat emosional dan sensual: cinta kepada Allah, takut akan azab Allah, tidak putus asa akan rahmat Allah, cinta dan senang berbuat kebajikan kepada sesama, menahan marah dan bisa mengendalikan kemarahan, tidak suka memusuhi orang lain dan menyakitinya, tidak dengki pada orang lain, tidak menyombongkan diri, penyayang.

7. Sifat-sifat intelektual dan kognitif: memikirkan alam 
semesta dan ciptaan Allah, selalu menuntut ilmu, tidak mengikuti sesuatu yang masih dugaan, teliti dalam meneliti suatu realitas. Sifat-sifat yang berkenaan dengan kehidupan praktis dan profesional: tulus dalam bekerja dan menyempurnakan pekerjaan, berusaha dengan giat dalam upaya memperoleh rezeki. Sifat-sifat fisik: kuat, sehat, bersih, dan suci dari najis ${ }^{25}$.

Selama ini pemahaman tentang keimanan hanya dimaknai dalam pengartian beriman kepada Allah, Tuhan Yang Maha Esa. Mempercayai saja keesaan Zat, Sifat, dan Perbuatan Tuhan, tanpa mengucapkan dengan lisan serta tanpa mengamalkan dengan perbuatan, tidak dapat dikatakan seorang yang sudah beriman secara sampurna. Penulis memandang, yang dimaksud dengan keimanan adalah tercermin dalam ibadah dan dalam perbuatan praktis kehidupan manusia seharihari, dengan kata lain, harus ada kesatuan dan keharmonisan tauhid teoretis dan tauhid praktis dalam diri dan dalam kehidupan sehari-hari secara murni dan konsekuen.

Mengokohkan keimanan, seseorang harus menyatukan iman dan amal, konsep dan pelaksanaan, fikiran dan perbuatan, serta teks dan konteks. Apabila keimanan kepada rukun iman tertanam dengan baik dan kokoh dalam setiap jiwa orang yang beriman, maka ia akan memberikan pengaruh dalam kehidupannya. Diantara pengaruh dan hikmah aqidah keimanan bagi kehidupan manusia adalah: Meluaskan pandangan dan menguatkan kebesaran jiwa, Menumbuhkan keberanian dan kepercayaan diri. Menumbuhkan kesabaran dan ketahanan mental,Menghilangkan perasaan kesepian. Menumbuhkan ketenangan dan ketentraman jiwa ${ }^{26}$.

Seseorang yang beriman akan terbebas dari ketakutan, kepanikan dan keluh kesah serta terhiasi dengan kesabaran, kebenaran. Akan terbebas dari jiwa yang kikir dan rakus terhadap dunia, terhiasi dengan kemuliaan, kemurahan serta kedermawanan. Selain itu, terbebas dari jeratan hawa nafsu, bujuk rayu setan dan nafsu amarah serta terhiasi dengan muqarabah kepada Allah, ikhlas kepada-Nya dan senatiasa

${ }^{25}$ Ibid hal 258

${ }^{26}$ Jaya, Yahya. Psikoterapi Agama Islam. Padang: IAIN IB Press 1999 hal 83 
memohon pertolongan-Nya, sehingga terdapat banyak pengaruh iman dalam kehidupan manusia, karena orang yang beriman akan merasa tenang dan aman karena memiliki perasaan dilindungi oleh Allah selalu bersikap optimis dan tidak putus asa dalam menjalani kehidupannya. Orang yang beriman adalah orang yang selalu ingat kepada Allah Swt, maka perasaan tenang aman dan terlindung akan selalu menyertainya. Orang yang beriman menjalani kehidupan di dunia tidak ada yang ditakutkannya selain Allah Swt karena Allah selalu memberikan petunjuk, taufik serta hidayah-Nya, sehingga orang beriman senantiasa memperoleh bimbingan dan perlindungan$\mathrm{Nya}^{27}$

Keimanan seseorang berbanding lurus dengan akhlak seseorang atau dengan kata lain semakin baik keimanan seseorang maka semakin baik pula akhlaknya, hal ini karena keimanan adalah modal utama untuk membentuk pribadi seseorang. Keimanan merupakan potensi yang ada pada manusia sejak ia lahir dan melekat pada dirinya hanya saja sejalan dengan pertumbuhan dan perkembangan seseorang yang telah terjamah oleh lingkungan sekitarnya maka potensi tersebut akan semakin muncul atau sebaliknya potensi itu akan hilang secara perlahan. Oleh karenanya keimanan merupakan hal yang prinsip dan perlu dibina secara kontinyu, terutama bagi mualaf yang membutuhkan bimbingan serta uswah oleh pembimbingnya, karena lingkungan yang mendukung untuk terus belajar mengenai agama akan membentuk pola dan sikap pada mualaf tersebut.

Orang-orang beriman tidaklah berada dalam peringkat yang sama, tapi berbeda-beda. Al-Quran sendiri telah mengemukakan tingkat atau kelompok orang-orang beriman, yaitu: orang-orang yang menganiaya diri sendiri, orang-orang yang berada di tengah-tengah, orang-orang yang bersegera dalam berbuat kebajikan. Sebagaimana firman Allah dalam alQuran surat Fathir ayat 32:

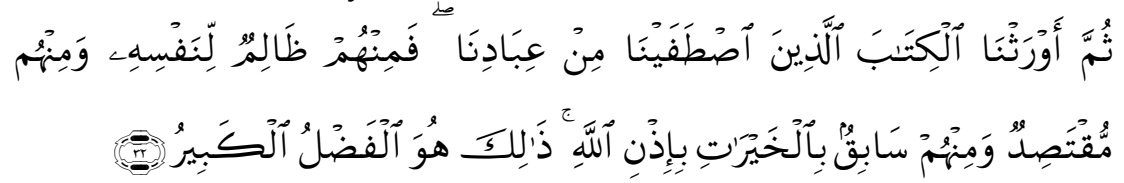

27 Ulwan, Abdullah Nashih.. Hiena Yajid al-Mu"min Halawat alIman, terj. Jakarta: Robbani Press1997 hal 105 
Artinya: kemudian kitab itu Kami wariskan kepada orangorang yang Kami pilih di antara hamba-hamba Kami, lalu di antara mereka ada yang Menganiaya diri mereka sendiri dan di antara mereka ada yang pertengahan dan diantara mereka ada (pula) yang lebih dahulu berbuat kebaikan dengan izin Allah. yang demikian itu adalah karunia yang Amat besar.

Al-Qurthubi dalam al-Mahali menafsirkan "orang yang menganiaya dirinya sendiri" ialah orang yang melakukan dosadosa kecil, sedang "orang yang pertengahan" ialah orang memberi dunia dan akhirat haknya masing-masing. Sementara "orang yang cepat berbuat kebaikan" ialah orang yang paling cepat dalam berbuat kebaikan. Sedangkan dalam Tafsir Jalalain dijelaskan bahwa "orang yang menganiaya dirinya sendiri" ialah orang yang terbatas dalam beramal kebaikan, sedang "orang yang pertengahan" ialah orang yang dalam sebagian waktu berbuat kebaikan. Sementara "orang yang cepat berbuat kbaikan"ialah orang yang di samping beramal kebaikan juga mengajarkan dan mengarahkan orang lain untuk beramal kebaikan. Iman terbagi atas beberapa tingkatan yakni:

a. Iman taqlid

Iman orang yang bertaqlid atau iman ikut ikutan, dia percaya kepada Allah dan Rasul tetapi kepercayaannya tanpa dalil, tanpa keterangan, tanpa pengetahuan. Orang ini imannya tidak teguh, mudah goyang dan goncang.

b. Iman ilmu

Keyakinan kepada Allah dan rasul sudah didukung dengan dalil- dalil, keterangan dan hujjah. Iman seperti ini belum sanggup melawan setan dan hawa nafsu. Orang beriman pada tingkat ini bisa melanggar perintah Allah secara sadar. Juga tidak sanggup menghadapi ujian-ujian hidup, apakah berupa kesenangan atau kesusahan. Jika mendapat kesenangan bisa lupa diri, bila mendapat kesusahan akan cemas dan kehilangan daya pertimbangan.

c. Iman ayyan

Iman ini adalah iman orang yang saleh atau iman ashab al-yamin yaitu orang yang senantiasa sadar bahwa Allah senantiasa mengawasi dirinya. Iman ayyan menjadikan seseorang memiliki kekuatan jiwa, gigih dan 
kuat cita-cita, tahan uji dan sanggup berkorban. Di samping itu iman ayyan mampu memacu umat menjadi umat yang gigih dalam memikul beban perintah Allah, juga meninggalkan segala larangan-Nya.

\section{G. HUBUNGAN BIMBINGAN AGAMA ISLAM DENGAN PEMBENTUKAN KEIMANAN MUALAF}

Agama merupakan landasan yang dapat memberikan pemahaman kepada manusia mengenai dimensi keagamaan sebagai faktor yang mempengaruhi kehidupan. Manusia yang percaya dan takwa kepada Allah SWT, menghayati dan mengamalkan ajaran agamanya dalam kehidupan sehari-sehari, baik dalam kehidupan pribadi maupun dalam kehidupan bermasyarakat dan mempertinggi budi pekerti agar dapat menumbuhkan manusia-manusia pembangunan yang dapat membangun dirinya sendiri serta bersama-sama bertanggung jawab atas pembinaan serta bimbingan kepada sesamanya. Ajaran agama dapat memberikan bimbingan hidup, memberikan kebahagiaan dan ketenangan serta dapat memberikan jalan penenang hati bagi jiwa yang sedang mengalami permasalahan.

Agama Islam menempatkan kedudukan manusia pada kedudukan yang mulia. Manusia diberi jabatan oleh Allah sebagai khalifah di bumi, tentu saja manusia memiliki keistimewaan dibandingkan dengan makhluk lain. Manusia diberi keanugerahan dan dibekali kemampuan. Kemampuan bawaan itu merupakan modal dasar yang akan tetap kerdil bila tidak ada usaha untuk mengembangkannya. Pengalaman yang terus menerus akan berkembang dan meluas, sehingga ketika menghadapi masalah, seseorang tidak akan terlalu sulit untuk mengatasinya. Melalui pendekatan agama seorang pembimbing akan mampu mengatasi permasalahan apapun yang dihadapi klien/jamaahnya. Agama mengatur segala kehidupan manusia, seperti mengatur bagaimana supaya hidup dalam ketentraman batin/jiwa atau dengan kata lain bahagia di dunia dan akherat.

Bimbingan agama akan mendorong orang yang mengalami kesulitan baik lahiriah maupun batiniah yang menyangkut kehidupan dimasa kini dan dimasa mendatang untuk mampu mengatasi dengan kemampuan yang ada dirinya 
sendiri melalui dorongan dengan kekuatan iman dan taqwanya kepada Allah Pokok iman adalah kalimat "lailaha illallah" tiada tuhan selain Allah. Aqidah Islam ini haruslah menjadi kepercayaan mutlak dan bulat, artinya keyakinan yang mutlak kepada Allah. Pokok aqidah adalah Allah SWT. Sebab dengan percaya kepada itu dengan sendirinya akan percaya pada malaikatnya, rasul-rasulnya, kitab-kitabnya, hari kemudian dan ketentuan takdirnya

Oleh karena itu bimbingan agama adalah membangkitkan daya rohaniah manusia serta meningkatkan iman dan taqwa kepada Allah SWT untuk mengatasinya segala kesulitan hidup yang dialami, jadi iman dan taqwa dibangkitkan sedemikian rupa sehingga menjadi tenaga pendorong terhadap kemampuan dirinya untuk mengatasi segala kesulitan hidup yang diatasi, hingga bangkit kesadaran sebagai pribadi yang harus mengarungi kehidupan nyata dalam masyarakat dan lingkungannya.

Keimanan seseorang berbanding lurus dengan akhlak seseorang atau dengan kata lain semakin baik keimanan seseorang maka semakin baik pula akhlaknya, hal ini karena keimanan adalah modal utama untuk membentuk pribadi seseorang. Keimanan merupakan potensi yang ada pada manusia sejak ia lahir dan melekat pada dirinya hanya saja sejalan dengan pertumbuhan dan perkembangan seseorang yang telah terjamah oleh lingkungan sekitarnya maka potensi tersebut akan semakin muncul atau sebaliknya potensi itu akan hilang secara perlahan. Oleh karenanya keimanan merupakan hal yang prinsip dan perlu dibina secara kontinyu, terutama bagi mualaf yang membutuhkan bimbingan serta uswah oleh pembimbingnya, karena lingkungan yang mendukung untuk terus belajar mengenai agama akan membentuk pola dan sikap pada mualaf tersebut.

Keimanan manusia dapat naik hingga derajat yang tinggi, maka dengan derajat yang tinggi itu, manusia mempunyai sebuah nilai yang dapat memasukkannya ke dalam surga, sebaliknya dengan kekafiran, derajat manusia akan turun ke derajat yang serendah-rendahnya, maka dengan derajat yang rendah itu manusia tidak mempunyai nilai dan tidak berharga, sehingga kelak dimasukkan ke dalam neraka. 
Iman merupakan nilai yang tidak terhingga harganya bagi manusia, sebab dengan iman dapat menghubungkan manusia dengan penciptanya. Hubungan manusia dengan Allah yang berdasarkan iman yang kuat ibarat hubungan nasab dan keturunan. Ini berarti sesuatu yang tidak mungkin dipisahkan, sebab tidak akan ada sesuatu kalau tidak ada yang menjadikannya ada, artinya sangat dekat sekali. Iman juga harus dipupuk dan ditingkatkan, yang semula iman taqlid harus naik satu level menjadi iman ilmu hingga sampai iman haq dan haqiqat, dengan begitu memelihara iman sangatlah penting adanya.

\section{H. URGENSI BIMBINGAN AGAMA ISLAM UNTUK PEMBENTUKAN KEIMANAN MUALAF}

Ikrar syahadat merupakan pintu gerbang untuk memasuki agama Islam. Sebagai orang yang baru masuk Islam perlu mengetahui apa yang ada dalam Islam, sehingga akan memberi manfaat baginya. Semakin banyak pengetahuan yang diperoleh akan semakin banyak manfaat yang diambilnya. Sementara itu, mualaf perlu mengetahui aturan-aturan yang ditetapkan dalam Islam, tidak hanya karena ingin memperoleh legitimasi formal berupa piagam, namun lebih dari itu adalah ilmu dan penerapannya mutlak dimiliki oleh mualaf. Karena status muallaf itu sudah sama dengan muslim lainnya, maka ia harus mengetahui kewajiban maupun hal-hal yang tidak boleh dikerjakannya.

Tahapan pembentukan keimanan ini, mualaf diwajibkan untuk mengikuti pengenalan dasar ke-Islaman yang dilaksanakan oleh pembimbing. Pengenalan dasar ke-Islaman ini bisa dilakukan secara privat maupun bersama-sama dan waktunya menyesuaikan. Adapun materinya meliputi : Pengenalan aqidah Islam, akhlak Islam, Thaharah dalam Islam, Teori dan praktek shalat, Pengenalan tentang zakat, puasa dan haji. Tujuan pengenalan dasar ke-Islaman kepada mualaf adalah memberi pembekalan dasar kepada mualaf dalam mempelajari dan mengamalkan Islam. Langkah selanjutnya juga untuk memotivasi dalam mempelajari Islam, sehingga Islam yang telah menjadi pilihannya benar-benar dirasakan dalam kehidupan sehari-hari. Hal ini juga dapat dilakukan dengan berguru kepada seorang guru agama, dapat pula belajar dengan teman 
seiman yang dianggap banyak tahu tentang Islam, atau dapat pula dengan memperbanyak membaca buku-buku Islami.

Bimbingan agama Islam merupakan upaya untuk membantu individu belajar mengembangkan fitrah atau kembali kepada fitrah, dengan memberdayakan iman, akal, dan kemauan yang dikaruniakan Allah SWT yang sifatnya berhubungan dengan agama ${ }^{28}$.Bimbingan agama Islam juga penting untuk membantu individu mewujudkan dirinya sebagai manusia seutuhnya agar mencapai kebahagiaan hidup di dunia dan akhirat. . Pemaparan tersebut memberikan pemahaman bahwa bimbingan agama Islam memang dibutuhkan dalam peningkatan keimanan seseorang terlebih seorang mualaf untuk menyadari dan mengembangkan eksistensinya kembali pada fitrah manusia.

Islam adalah agama fitrah, sehingga kebenaran dan kebaikan ajaran Islam sesuai dengan kebenaran dan kebaikan fitrah manusia. Maka dari itu, apabila terjadi keingkaran manusia terhadap ajaran Islam, maka dapat ditelusuri antara sebab internal dan eksternal. Faktor lingkungan dan hubungan sosial kemasyarakatan besar pengaruhnya terhadap fitrah manusia, karena sama besar pengaruhnya dengan faktor kejiwaan. Kedua faktor tersebut juga besar pengaruhnya bagi kuat dan lemahnya iman yang setiap saat dapat berubah karena kondisi internal dan eksternal. Hal ini karena pada prinsipnya keatangan aqidah menjamin hidup dunia dan akhirat, baik bagi individu dan masyarakat. Pemahaman ajaran Islam secara sungguh-sungguh akan mewujudkan kondisi dinamis dan konstruktif sehingga dapat mengantarkan manusia mencapai keharmonisan hidup dan kehidupan dalam segala aspeknya

\section{SIMPULAN}

Berdasarkan hasil uraian yang penulis lakukan, dapat disimpulkan bahwa:

Urgensi Bimbingan Keagamaan Islam Terhadap Pembentukan Keimanan Mualaf adalah sebagai berikut: Pelaksanaan bimbingan keagamaan Islam terhadap pembentukan keimanan mualaf Pada Semarang penting diterapkan untuk mualaf yang bermasalah maupun yang tidak,

28Sutoyo, Anwar Bimbimbngan Dan Konseling Islami (Teori Dan Praktik). Yogyakarta: Pustaka Pelajar 2013 hal 23 
karena pada dasarnya dengan adanya bimbingan agama Islam mualaf akan selalu mengingat Allah dan menjadi jalan lurus untuk menggapai hidup lebih tenang dan terarah. Bimbingan agama Islam di dilakukan dengan ceramah, diskusi agama, dan curahan hati. Selain itu, ada program harian seperti sholat berjamaah, materi qiyamul lail, ada pula waktu tertentu misalnya peringatan hari besar Islam, kajian keislaman dengan metode langsung maupun metode tidak langsung. Urgensi bimbingan agama Islam adalah :

Pertama, menghasilkan suatu perubahan, perbaikan, dan kebersihan jiwa dan mental yang semula masih minder menjadi percaya diri sehingga jiwa mualaf menjadi tenang dan damai, bersikap lapang dada, dan untuk menggapai pencerahan taufik hidayah Tuhannya lebih terasa ringan.

Kedua, untuk menghasilkan suatu perubahan kesopanan tingkah laku yang dapat memberikan manfaat baik pada diri sendiri, lingkungan keluarga, lingkungan kerja maupun lingkungan sosial dan alam sekitarnya.

Ketiga, untuk menghasilkan kepekaan sosial pada individu sehingga muncul dan berkembang rasa toleransi, kesetiakawanan, tolong menolong dan rasa kasih sayang. Kesalehan sosial akan menjadikan motivasi untuk meningkatkan sistem antibodi dari akhlaq al-madmumah sehingga ahkhlaq alkarimah selalu terjaga.

Keempat, untuk menghasilkan kecerdasan spiritual pada diri individu sehingga muncul dan berkembang rasa keinginan untuk berbuat taat kepada Tuhannya, ketulusan mematuhi segala perintah-Nya serta ketahanan menerima ujianNya. Keseluruhan urgensi dan prinsip di atas adalah sarana untuk meningkatkan kualitas keimanan semakin tumbuh dan kokoh, yang semula iman taqlid akan naik menjadi iman ilmu begitu selanjutnya sampai mencapai titik tertinggi yakni iman haq dan hakikat. 


\section{DAFTAR PUSTAKA}

Mustof, Kurdi. 2012. Dakwah Dibalik Kekuasaan. Bandung: Remaja Rosdakarya.

Bruce, Shertzer dan Shaelly C. Stone1966. Fundamental of Guidance. Boston: Houghton Mifflin Company

http://jurnalbki.uinsby.ac.id/index.php/jurnalbki/issue/view/ 15

Musnamar, Tohari. 1992. Dasar-Dasar Konseptual Bimbingan dan Konseling Islam, Yogyakarta: UII Press.

Faqih, Aunur Rohim. 2001. Bimbingan dan Konseling dalam Islam. Yogyakarta: UII Press

Bakran adz-Dzaky, M. Hamdani. 2001. Psikoterapi dan Konseling Islam. Yogyakarta: Fajar Pustaka Baru.

Latipun. 2001. Psikologi Konseling. Malang: UMM Press. Hallen. A. Bimbingan dan Konseling Cet. I. Jakarta: Ciputat Press 2001

Yusuf, Syamsul \& Juntika Nurihsan. 2011. Landasan Bimbingan $\mathcal{E}$ Konseling. Bandung: PT Remaja Rosdakarya.

Farid, Imam Sayuti. 1997. Pokok-Pokok Bahasan Tentang Bimbingan Penyuluhan Agama Sebagai Teknik Dakwah. Surabaya: Fakultas Dakwah IAIN Sunan Ampel

Willis, Sofyan S. 2010. Konseling Individual Teori dan Praktek. Bandung: Alfabeta

Santoso, Agus dkk. 2013. Terapi Islam. Surabaya: IAIN SA Press.

Shihab, Quraish. 2011. Membumikan al-Quran Memfungsikan Wahyu dalam Kehidupan, jilid 2. Ciputat Tangerang: Lentera Hati. 
90 | Bimbingan Penyuluhan Islam, Vol. 1, No. 1 Januari-Juni 2019

Syukir, Asmuni. 1983. Dasar-dasar Strategi Dakwah Islam. Surabaya: Al-Ikhlas.

Ulwan, Abdullah Nashih 1997. Hiena Yajid al-Mu"min Halawat alIman, terj. Jakarta: Robbani Press 